\title{
Atmospheric Volatile Organic Compounds and Ozone Creation Potential in an Urban Center of Southern Nigeria
}

\author{
Emmanuel Gbenga Olumayede \\ Department Industrial Chemistry, Faculty of Sciences, Federal University Oye-Ekiti, Ekiti State 234-80343451, Nigeria \\ Correspondence should be addressed to Emmanuel Gbenga Olumayede; emmanuel.olumayede@fuoye.edu.ng
}

Received 16 April 2014; Revised 5 August 2014; Accepted 8 August 2014; Published 21 August 2014

Academic Editor: Francesco Cairo

Copyright (c) 2014 Emmanuel Gbenga Olumayede. This is an open access article distributed under the Creative Commons Attribution License, which permits unrestricted use, distribution, and reproduction in any medium, provided the original work is properly cited.

\begin{abstract}
The relative contribution of individual volatile organic compounds (VOC) species to photochemical ozone formation depends on their atmospheric concentrations and their oxidation mechanism. In an attempt to evaluate the ozone creation potential of ambient VOCs captured in an urban settlement of Benin City, Nigeria, the VOCs concentrations data collected in field studies at nine measurement sites of different air quality in the city and a background site were analysed. Air samples were collected at human breathing height of 1.5 meters from ground level at each site. Active sampling method using the low volume sampling pump (Acuro, Drager, Lubeck, Germany) was used to drawn the air into the tube; the absorbent was Chromosorb 106. The sampling periods were between May 2010 and June 2011; the period covered both dry and wet seasons. The adsorbed gases were desorbed using solvent extraction method with carbon disulphide as solvent. The extracted solutions were analyzed with gas chromatography and mass spectrometer. The observed concentrations of individual VOCs were determined and maximum incremental reactivity (MIR) coefficient along with rate constants of VOC-OH reactions were applied to assess the ozone formation potential of individual VOC in the ambient atmosphere. Sixteen VOC species were observed at various sites with mixing height in decreasing order: toluene (5.82), mp-xylene (3.58), ethylbenzene (3.46), benzene (2.29), and n-butane (0.84). The ozone formation potential study revealed that, ranking by propyl-equivalent, the alkanes included in this study account for $58 \%$ of the total propyl-equivalent concentration. The total ozone creation potential in the atmosphere of the Benin City was calculated to be $281.1 \mu \mathrm{g} / \mathrm{m}^{3}$. A comparison of total ozone formation potential (OFP) in our study with results obtained from other cities of the world revealed that the total concentration of ozone production in our study is threefold lower than the values reported in China city of Foshan. It is suggested that the sources of this pollutant need to be monitored in the area as a way of curtailing the impact of ozone in this city.
\end{abstract}

\section{Introduction}

Monitoring of volatile organic compounds (VOCs) is a key piece in understanding photochemical air quality in urban atmosphere. VOCs degradation in the atmosphere contributes significantly to the generation of secondary air pollutants, such as aldehydes and peroxyacetyl nitrate (PAN) secondary aerosol [1]. Anthropogenic sources such as incomplete combustion of organic substances, the use of petrochemical solvents, and vaporizations of petroleum products [2] are sources of VOCs. Studies on the relationship between VOCs profiles and emission sources in ozone episode regions have shown that ozone formation is VOC limited [3]. Elevated levels of volatile organic compounds are known to be prevalent in the atmosphere of most world cities [4-9]. VOCs in cities atmosphere consist of hundreds of nonmethane hydrocarbons and each of them has different reaction rate, lifetime, and reaction mechanisms in the atmosphere [10-12]; hence, the relative contribution of individual VOC species to the photochemical $\mathrm{O}_{3}$ formation varies from one compound to another $[13,14]$ and from region to region. Reactive VOCs such as olefins are important in the formation of tropospheric ozone $[15,16]$. Ozone is produced by a complex reaction taking place among $\mathrm{NO}_{x}$ and VOCs in presence of sunlight $[1,3]$. Thus, there is a need to understand both the distribution and chemical reactivity of the VOCs.

Several studies have provided information on reactivity and ozone creation potentials of nonmethane hydrocarbons 
in some cities of the world [17-20]. Unfortunately, most of such studies are in atmosphere of Asian and European cities. Until recent time, when we began the studies of VOCs and ozone formation [21] in Nigeria cities, studies have so far been rather limited to atmospheric levels and the variations pattern in ambient atmosphere [22-24].

Benin City, Southern Nigeria, is one of the urban settlements in the country's oil-rich zone. It is the administrative headquarter of Edo states and a transitory city leading to the southern, southwestern, and northern parts of the country. The city has a population of about 1.3 million inhabitants [25] and steady traffic density especially during the weekdays. Recent reports on the climatic pattern in Nigeria, especially southern part where Benin city belongs to, showed increasing trend in both rainfall and temperature as a major feature of, or evidence of, climate change in the City [26]. Air pollution studies [27] in the city also revealed increase in ozone levels along with $\mathrm{NO}_{x}$ concentration due to increase traffic activities in the city. Currently, the recent increase in importation of second-hand cars and wide spread adaptation of single engine "okada" motorcycles for ferrying passengers have accentuated the general levels of atmospheric hydrocarbon.

As part of our efforts in understanding the behaviors of VOCs in the atmosphere of Nigerian cities, this paper is aimed at identifying key VOC species and assessing the reactivities of each VOC in the atmosphere of Benin City, Southern Nigeria. The study also includes evaluation of the relative ozone-forming potentials of the captured VOC species in the atmosphere of this urban settlement of Southern Nigeria from data obtained between May 2010 and June 2011. Hopefully, the study will provide data that would assist in understanding the processes of reaction rate and degradation of atmospheric VOCs and helpful in better policy formulation towards reduction of the impacts of ozone in the areas.

\section{Methodology}

2.1. The Study Area. Benin City, Southern Nigeria, is located between longitude $6.20^{\circ} \mathrm{N}$ and latitude $5.31^{\circ} \mathrm{E}$. It is situated within the equatorial climatic belt (Af Koppen's climatic classification) and is one of the urban centers in southern part of the country with about 1.3 million habitants [25]. It is the administrative headquarter of Edo states; hence, an urban residential area with high population and steady traffic density especially during the weekdays. The city lies within such areas which receive adequate rainfall of between $2000 \mathrm{~mm}$ and $3000 \mathrm{~mm}$ annually. Its mean monthly temperature and relative humidity are $28^{\circ} \mathrm{C}$ and $80 \%$, respectively [26]. Benin City is about $85 \mathrm{~m}$ above the sea level at the highest point.

2.2. Sampling Locations. Table 1 gives the coordinate and description of the sampling locations for the collection of our data within Benin City. The study sites were carefully chosen to reflect the different pattern of human activities dominating in the areas. The sampling procedures have been discussed in our previous work [21]. The sampling period covers wet and dry seasons at different sites to highlight the temporal variability.
2.3. Samples Collection. Samples of ambient air were collected using active sampling method. The air was withdrawn by low volume pump at controlled air flow and adsorbed into Chromosorb 106 as adsorbent. The sensitivity and reliability of the sampling approach have been reported [28, 29].

2.4. Chemical Extraction and Analysis. After sampling, adsorption tubes were labeled and closed with special caps to avoid contamination. The desorption process, chemical extraction, and analysis have been discussed elsewhere [21, 22].

2.5. Quality Assurance/Control. A quality assurance program was implemented in the framework of which all analytical systems related to the analysis of VOCs have been checked for their performance. Laboratory and field blanks analysis were carried out during each sampling period. Extraction solvent $\left(\mathrm{CS}_{2}\right)$ was also analyzed. The blank activated carbon tubes as well as process blank were analyzed to determine if there was any contamination in the activated carbon tubes. None of the compounds included in this study were detected in $\mathrm{CS}_{2}$ and in process blanks. The efficiency of the adsorbent was tested by using a backup tube after a sampling. Sampling efficiency of acetone and acetate was found to be $87 \%$ and $73 \%$, respectively.

Various quality control tools were used in order to ensure that adequate laboratory performance was maintained. These included control charts for standard solutions and analysis of control standards as unknowns. The calibration curve was found to show good linearity, with determination coefficients $\left(r^{2}\right)$ greater than 0.999 for all the compounds. The limits of detection for BTEX were determined for most VOCs using sample volume of $10 \mathrm{~mL}$ and the values calculated in absolute mass. The limits of detection for carbonyls were found to be $0.1 \mu \mathrm{gm}^{-3}$ for acetone and $0.1 \mu \mathrm{gm}^{-3}$ for benzene, toluene, ethyl benzene, $\mathrm{m}, \mathrm{p}$-xylene, and $0.2 \mu \mathrm{gm}^{-3}$ for o-xylene.

2.6. Estimation of Ozone Formation Potential. Recently, different methods are used to define the reactivity for ozone forming potential from nonmethane hydrocarbon. In this study, the contribution of individual VOC to ozone formation was also studied according to the propylene-equivalent concentration $[30,31]$ and maximum incremental reactivity (MIR) methods [32].

Propylene-equivalent is a measure of the concentration of hydrocarbon on an $\mathrm{OH}$-reactivity based scale normalized to the reactivity of propene. The propylene-equivalent is defined as

$$
\text { Propylene-equivalent }=\frac{C_{i} \times K_{\mathrm{OH}(i)}}{K_{\mathrm{OH}\left(\mathrm{C}_{3} \mathrm{H}_{6}\right)}},
$$

where $C_{i}$ is defined as a concentration of individual VOC species, $K_{\mathrm{OH}(i)}$ is the rate constant for the reactivity of individual VOC, and $\mathrm{K}_{\mathrm{OH}\left(\mathrm{C}_{3} \mathrm{H}_{6}\right)}$ is the rate constant for reaction of $\mathrm{C}_{3} \mathrm{H}_{6}$ with $\mathrm{OH}$ radical. 
TABLE 1: The coordinate and description of the sampling locations.

\begin{tabular}{|c|c|c|c|}
\hline sSite & Site code & Coordinates & Site description \\
\hline 1 & BNAR & 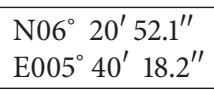 & Created along Ramat park, close to a petroleum depot and two breweries \\
\hline 2 & BNUG & $\begin{array}{l}\mathrm{N}^{\circ} 6^{\circ} 24^{\prime} 10.1^{\prime \prime} \\
\mathrm{E}_{00} 5^{\circ} 36^{\prime} 32.2^{\prime \prime}\end{array}$ & $\begin{array}{l}\text { Ugbowo monitoring site created at the University of Benin main gate and close to } \\
\text { fuel dispensing stations along the express way to the western part of the country }\end{array}$ \\
\hline 3 & $\mathrm{BNNB}$ & $\begin{array}{l}\mathrm{N}^{\circ} 6^{\circ} 20^{\prime} 57.3^{\prime \prime} \\
\mathrm{E}^{\prime \prime} 05^{\circ} 37^{\prime} 25.1^{\prime \prime}\end{array}$ & $\begin{array}{l}\text { Site three created at New Benin bus terminal. A location with very high traffic } \\
\text { density and petroleum products dispensing stations }\end{array}$ \\
\hline 4 & BNRR & $\begin{array}{l}\mathrm{N} 06^{\circ} 38^{\prime} 45.1^{\prime \prime} \\
\mathrm{E}_{005^{\circ}} 37^{\prime} 20.1^{\prime \prime}\end{array}$ & Created at the King's square with many road intersections and high traffic density \\
\hline 5 & BNSP & $\begin{array}{l}\mathrm{N}^{\circ} 6^{\circ} 17^{\prime} 44.6^{\prime \prime} \\
\mathrm{E}^{\prime \prime} 5^{\circ} 38^{\prime} 8.9^{\prime \prime}\end{array}$ & Created along Sapele road very close to the Santana market \\
\hline 6 & BNEN & $\begin{array}{l}\mathrm{N}^{\circ} 6^{\circ} 19^{\prime} 28.4^{\prime \prime} \\
\mathrm{E}_{005^{\circ}} 35^{\prime} 99.3^{\prime \prime}\end{array}$ & Ekenwan site close to the University of Benin postgraduate student hostel \\
\hline 7 & BNOL & $\begin{array}{l}\mathrm{N}^{\circ} 6^{\circ} 19^{\prime} 17.8^{\prime \prime} \\
\mathrm{E}_{005^{\circ}} 38^{\prime} 12.5^{\prime \prime}\end{array}$ & 3rd East Circular road site with many road intersections \\
\hline 8 & BNAU & 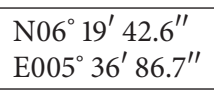 & Upper Adesuwa in GRA, close to Word of Faith secondary school \\
\hline 9 & BNSP & $\begin{array}{l}\mathrm{N}^{\circ} 6^{\circ} 18^{\prime} 28.4^{\prime \prime} \\
\mathrm{E}^{\prime \prime} 5^{\circ} 38^{\prime} 16.5^{\prime \prime}\end{array}$ & Upper Sakponba junction, a bus stop with many shops \\
\hline 10 & BNEK & $\begin{array}{l}\mathrm{N}_{0} 6^{\circ} 38^{\prime} 45.1^{\prime \prime} \\
\mathrm{E} 005^{\circ} 46^{\prime} 00.5^{\prime \prime}\end{array}$ & Odighi site, a background site, created close village square \\
\hline
\end{tabular}

The ozone formation potential is evaluated as product of the concentration of each VOC and the maximum incremental reactivity coefficient (MIR). The MIR is defined as

$$
\mathrm{OFP}_{(i)}=\text { concentration }_{(i)} \times \mathrm{MIR} \text { coefficient }_{(i)},
$$

where $\mathrm{OFP}_{(i)}$ is defined as ozone formation potential of individual hydrocarbon $i$ and MIR coefficient ${ }_{(i)}$ is the maximum incremental reactivity coefficient of compound $i$, [32].

\section{Results and Discussion}

3.1. General Distributions of Total Volatile Organic Compounds in Atmosphere of Benin City. Ambient VOCs data for this study were the measured data generated between May, 2010, and June, 2011. In our previous report [20], a total of fifteen volatile organic compounds species were successfully identified and quantified in ambient air of Benin City, amongst which were four alkanes, 6 aromatic compounds, 3 chlorinated hydrocarbons, and 1 carbonyl compound. These compounds were used in this study. The total concentration of VOCs was obtained by summing the concentrations of individual species detected.

Figure 1 presents the TVOCs distribution by compound types in the sampling sites of Benin City. The figure clearly showed spatial variation in VOC speciation in the nine sites for the measurements. The most abundant class of VOCs species in atmosphere of the studied center are aromatic hydrocarbons, aliphatic, carbonyl, and halogenated compounds. Aromatic accounted for between 61 and $77 \%$ in most sites; this was followed by aliphatic $20-7 \%$, while $5-21 \%$ halogenated compounds and carbonyl followed. Comparing the percentage of VOCs grouping in this study with similar urban centers earlier studied, Foshan, China, [12] shows that

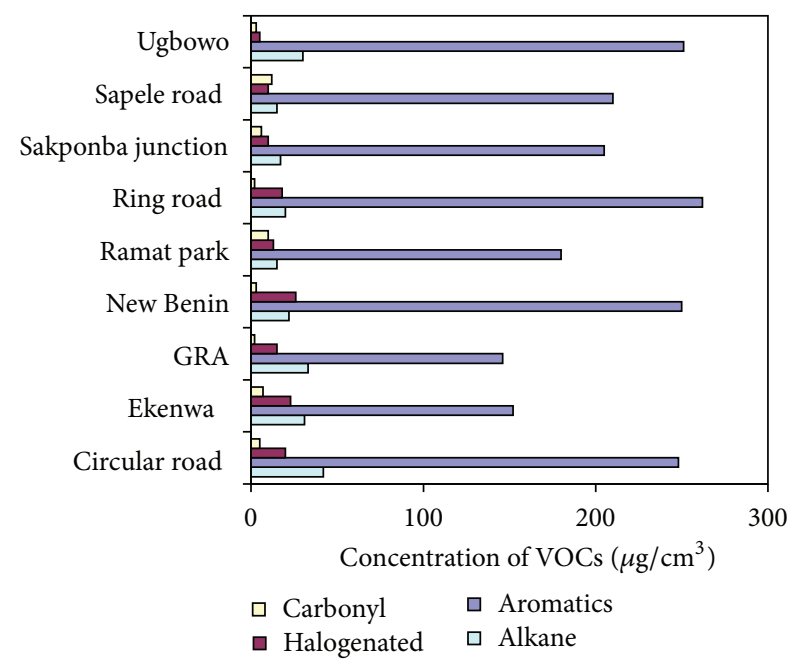

FIGURE 1: Plot of mean values of TVOCs of different classes in atmosphere of Benin City.

the compositions of VOCs in Benin City showed similarities with those of anthropogenic traffic impacted urban centers.

3.2. Mixing Ratios of Ambient VOC Species in Benin City. Table 2 presents the VOC composition and descriptive statistics of the observed VOCs species at the sampling sites of Benin City. In terms of composition, the VOC species in Benin City compared with the observed VOCs in others cities of the world (Hong Kong) [33] (Guangzhou, China) [34] as hydrocarbon such as n-butane, isopentane, toluene, xylene isomers, ethylbenzene, and benzene are abundant. The mixing ratios of the individual VOCs was obtained by 
TABLE 2: Composition and descriptive statistic of the observed VOCs.

\begin{tabular}{lcccc}
\hline VOC species & Mean \pm SD & Morning & Afternoon & Evening \\
\hline n-Butane & $0.84 \pm 0.01$ & $0.79 \pm 0.04$ & $0.75 \pm 0.16$ & $0.1 \pm 0.02$ \\
Isopentane & $0.1 \pm 0.01$ & $0.1 \pm 0.04$ & $0.98 \pm 0.02$ & $0.1 \pm 0.08$ \\
2-Methylpentane & $0.95 \pm 0.67$ & $0.8 \pm 0.07$ & $0.08 \pm 0.02$ & $1.09 \pm 0.08$ \\
3-Methylpentane & $0.09 \pm 0.33$ & $0.1 \pm 0.01$ & $0.62 \pm 0.07$ & $0.1 \pm 0.01$ \\
Undecane & $0.54 \pm 0.13$ & $0.87 \pm 0.08$ & $2.71 \pm 0.19$ & $0.14 \pm 0.01$ \\
Benzene & $2.29 \pm 1.07$ & $2.03 \pm 0.16$ & $5.87 \pm 0.54$ & $2.15 \pm 0.07$ \\
Toluene & $5.82 \pm 0.67$ & $5.6 \pm 0.96$ & $3.08 \pm 0.05$ & $6.01 \pm 1.03$ \\
Ethylbenzene & $3.46 \pm 1.33$ & $3.84 \pm 0.53$ & $3.81 \pm 0.92$ & $3.47 \pm 1.14$ \\
m,p-Xylene & $3.58 \pm 1.11$ & $3.72 \pm 1.03$ & $2.26 \pm 0.14$ & $3.21 \pm 0.79$ \\
o-Xylene & $2.23 \pm 0.33$ & $2.24 \pm 0.58$ & $1.03 \pm 0.08$ & $2.2 \pm 0.05$ \\
Naphthalene & $0.88 \pm 0.06$ & $0.73 \pm 0.11$ & $1.02 \pm 0.04$ & $0.9 \pm 0.04$ \\
Methylene chloride & $0.79 \pm 0.01$ & $0.67 \pm 0.02$ & $0.97 \pm 0.10$ & $0.69 \pm 0.02$ \\
Tetrachloroethane & $0.96 \pm 0.12$ & $0.89 \pm 0.06$ & $0.06 \pm 0.02$ & $1.03 \pm 0.08$ \\
Carbon tetrachloride & $0.03 \pm 0.01$ & $0.04 \pm 0.01$ & $0.27 \pm 0.04$ & $0.01 \pm 0.01$ \\
Chloroform & $0.24 \pm 0.03$ & $0.28 \pm 0.09$ & $1.02 \pm 0.30$ & $0.18 \pm 0.03$ \\
Acetone & $0.92 \pm 0.11$ & $0.85 \pm 0.16$ & & $0.9 \pm 0.12$ \\
\hline
\end{tabular}

finding the average mean concentrations obtained in the nine sampling sites. On the basis of average concentrations, the most abundant VOCs were in decreasing order: toluene (5.82), mp-xylene (3.58), ethylbenzene (3.46), Benzene (2.29), and n-butane (0.84). A comparison of the mixing ratios in our study with earlier reports from cities in Asia (Seoul), Europe, and other parts of the world previously studied $[8,12,21]$ the values revealed that the obtained values in this study are lower than those measured in most Asian cities. The variation may be attributed to population difference in these cities.

A cursory look at the distribution pattern of VOC species in Benin City revealed that aromatic hydrocarbons (BET) were ranked among the VOCs species with high concentrations. The sources of aromatics in the atmosphere cities are fuel combustion and evaporation of fuel and solvents $[8,9]$ along with emissions from industrial solvents and evaporative such as cosmetics, paints application, printing processes, dry cleaning, use of air-conditioning; photocopies, and lamination machines. The possible sources of these compounds in Benin City are the small scale industries located in the City.

Among the alkanes, isopentane and n-butane have highest mean concentrations of $0.35 \mu \mathrm{gm}^{-3}$ and $0.34 \mu \mathrm{gm}^{-3}$, respectively, in the city. Isopentane is a typical tracer of gasoline evaporation $[5,12]$. Gasoline evaporation is common in the city, as open displayed of the product and marketing of LP in most parts of the city. Halogenated hydrocarbons are emitted from a wide variety of industrial activity, both big factories and smaller business, from land fill and other waste processing activity. According to Singh et al. [35] the main sources of acetone are primarily biogenic decaying plant matter, biomass burning, and direct anthropogenic sources. The possible sources for acetone in Benin City are biogenic sources and anthropogenic especially the indiscriminate discharge of refuse.

3.3. Diurnal Variations. Table 2 also presents the diurnal distribution of VOC species in Benin City. The distribution pattern revealed that some species showed bimodal pattern with morning and evening peaks. The diurnal pattern of aromatics (BEX) was observed to follow a similar pattern, indicating that these compounds have a similar source and dispersion pattern, with high concentrations in the morning and during afternoon. In most Nigerian cities, emissions from vehicle traffic begin at around 6.00 a.m and stay till 9.00 a.m. This period coincides with the hours of maximum traffic volume as a result of the rush to get to the offices, schools, and the city markets. Therefore the two peaks indicate emissions of vehicles related pollutants dominated in the city. The observations in this study agree well with earlier reports that low wind speed is responsible for poor dispersion and dilution of pollutants in atmosphere $[25,27]$.

3.4. Ozone Formation Potential. According to Wang et al. [16], the actual amount of ozone produced by a given hydrocarbon depends on their particular oxidation mechanism and their abundance. Under typical atmospheric conditions, reactions with the hydroxyl radical are the most rapid and account for a large portion of pollutant degradation during daylight hours. One of the objectives of this study is to examine the relative importance of the abundant atmospheric hydrocarbon compounds for their potential role in the production of ozone. For this purpose, we estimate the reactivity of the abundant hydrocarbon with hydroxyl radical $(\mathrm{OH})$ in each studied centre, which represents the contribution of each species to the $\mathrm{OH}$ lost rate.

Table 3 presents the reactivity of hydrocarbons measured in the atmosphere of Benin City relative to $\mathrm{OH}$ radical. The result in our study shows that, ranking by propyl-equivalent, the alkanes included in this study, butane, isopentane, methylpentane, and methylhexane, account for $58 \%$ of the total propyl-equivalent concentration.

The total ozone creation potential in the atmosphere of the Benin City was calculated to be $281.1 \mu \mathrm{g} / \mathrm{m}^{3}$. The highest photochemical $\mathrm{O}_{3}$ formation of $25.7 \mu \mathrm{g} / \mathrm{m}^{3}$ comes from 
TABLE 3: Reactivity and ozone formation potential of the measured VOCs in atmosphere of Benin City.

\begin{tabular}{|c|c|c|c|c|c|c|}
\hline VOC species & Group & $K_{\mathrm{OH}}{ }^{*}$ & $\mathrm{OH}$ reactivity & Prop-equiv. & MIR & OFP \\
\hline n-Butane & \multirow{5}{*}{ Aliphatic } & 2.54 & 0.86 & 0.03 & 1.08 & 0.367 \\
\hline Isopentane & & 5.6 & 1.96 & 0.08 & 1.36 & 0.476 \\
\hline 2-Methylbutane & & 2.59 & 0.96 & 0.04 & 1.11 & 0.411 \\
\hline 3-Methylpentane & & 3.7 & & 0.05 & 1.7 & 0.595 \\
\hline \multicolumn{6}{|l|}{ Undecane } & \\
\hline Benzene & \multirow{6}{*}{ Aromatic } & 11.2 & 26.43 & 1.01 & 0.55 & 1.298 \\
\hline Toluene & & 1.23 & 2.90 & 0.11 & 0.69 & 1.628 \\
\hline Ethylbenzene & & 5.96 & 12.28 & 0.47 & 3.88 & 7.993 \\
\hline m,p-Xylene & & 7.1 & 26.70 & 1.02 & 2.93 & 11.02 \\
\hline o-Xylene & & 19 & 32.11 & 1.22 & 15.21 & 25.7 \\
\hline Naphthalene & & 13.7 & 7.12 & 0.27 & 7.44 & 3.869 \\
\hline Methylene chloride & & & & & 3.24 & 0.194 \\
\hline Carbon tetrachloride & & & & & 0.036 & 0.006 \\
\hline Chloroform & & & & & 0 & 0 \\
\hline \multirow[t]{2}{*}{ Acetone } & & & & & 0.02 & 0.002 \\
\hline & & & & & 0.35 & 0.147 \\
\hline
\end{tabular}

${ }^{*} K_{\mathrm{OH}}$ corresponds to the reaction rate coefficient $\left(\mathrm{cm}^{3}\right.$ molecule $\left.{ }^{-1} \mathrm{~s}^{-1}\right) \times 10^{-12}$ published by Atkinson [15].

$\mathrm{OH}$ reactivity: product of mean individual VOC concentration and $\mathrm{OH}$ reaction rate coefficient.

$\mathrm{m}, \mathrm{p}$-xylene. This is followed in decreasing order by ethylbenzene $\left(11.02 \mu \mathrm{g} / \mathrm{m}^{3}\right)$, undecane $\left(26.43 \mu \mathrm{g} / \mathrm{m}^{3}\right), 1,2,4$-trimethylbenzene $\left(18.85 \mu \mathrm{g} / \mathrm{m}^{3}\right)$, and toluene (12.27). The results showed slight variation from our observation at Akure and Ado-Ekiti, Southwestern Nigeria, in a previous study [21]. These results indicate that aromatics played the most significant role in $\mathrm{O}_{3}$ formation in the studied center. Guo et al. [34] also found that m-, p-xylene and toluene were ranked high in ozone formation in urban Hong Kong where the reactivity of VOC was dominated by anthropogenic sources. The fact that undecene, an aliphatic group and heavy hydrocarbon from diesel combustion, was ranked among the highest contributions to ozone formation in our study suggested that this pollutant needs to be monitored in the area. This is imperative as alkanes have longer lifetimes and can be transported farther from their sources; hence they can produce a higher concentration of ozone even though the local concentrations are very low.

Figure 2 shows the ozone formation potential at each sampling site of Benin City. It can be observed that the highest ozone concentration was observed at Sapele road. The site is also located toward the outskirt of the city; hence this observation may be attributed to the proximate of this sampling site to most refuse disposal sites around the sampling site.

A comparison of total ozone formation potential (OFP) in our study with results from other cities of the world revealed that the total concentration of ozone production in our study is 3-fold lower than the value of $863.4 \mu \mathrm{g} / \mathrm{m}^{3}$ reported in Foshan, China [32].

\section{Conclusions}

The VOC concentration in ambient air of an urban settlement of Benin City was studied to understand the distribution

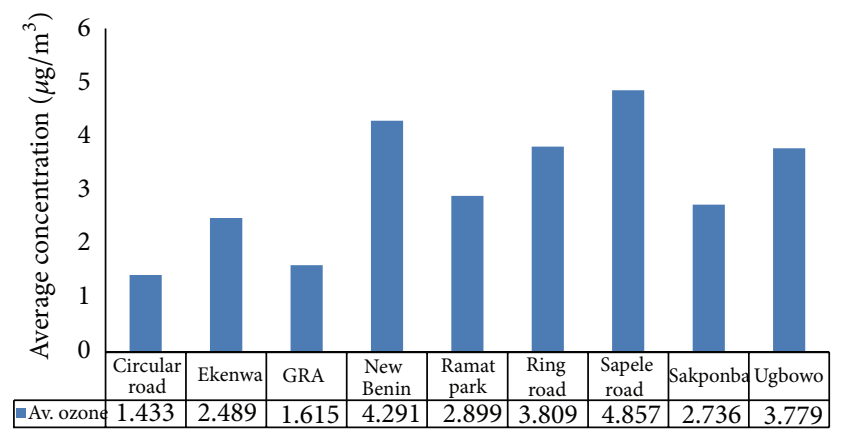

- Av. ozone

FIGURE 2: Spatial variation of ozone in sampling sites of Benin City.

patterns. The TVOCs were found to show significant spatial variation among the nine sampling sites of Benin City. The diurnal trend of TVOCs concentrations showed bimodal peaks with morning and evening peaks which followed the traffic pattern of the study centers and suggest the importance of vehicular emission. The prevalence of low wind speed in the studied centers was also observed to be responsible for the poor dilution and dispersion of the emitted VOCs. Evaluation of ozone formation potentials of the four classes of hydrocarbons detected showed that aromatics play important roles in ozone formation in the centres.

\section{Conflict of Interests}

The author declares that there is no conflict of interests regarding the publication of this paper. 


\section{Acknowledgment}

The author wishes to express gratitude to ETF fund for the sponsorship of this research work.

\section{References}

[1] A. Srivastava, A. E. Joseph, A. More, and S. Patil, "Emissions of VOCs at urban petrol retail distribution centres in India (Delhi and Mumbai)," Environmental Monitoring and Assessment, vol. 109, no. 1-3, pp. 227-242, 2005.

[2] S. Sillman, "The use of $\mathrm{NO}_{X}, \mathrm{H}_{2} \mathrm{O}_{2}$, and $\mathrm{HNO}_{3}$ as indicators for ozone- $\mathrm{NO}_{x}$ - hydrocarbon sensitivity in urban locations," Journal of Geophysical Research, vol. 100, no. 7, pp. 14175-14188, 1995.

[3] S. C. Lee, M. Y. Chiu, K. F. Ho, S. C. Zou, and X. Wang, "Volatile organic compounds (VOCs) in urban atmosphere of Hong Kong," Chemosphere, vol. 48, no. 3, pp. 375-382, 2002.

[4] B. Barletta, S. Meinordi, S. F. Rowland et al., "VOCs in 43 Chinese Cities," Atmospheric Environment, vol. 39, pp. 59795990, 2005.

[5] A. Srivastava, "Source apportionment of ambient VOCS in Mumbai city," Atmospheric Environment, vol. 38, no. 39, pp. 6829-6843, 2004.

[6] K. Na, Y. P. Kim, K.-C. Moon, I. Moon, and K. Fung, "Concentrations of volatile organic compounds in an industrial area of Korea," Atmospheric Environment, vol. 35, no. 15, pp. 2747-2756, 2001.

[7] K. Na, Y. P. Kim, and K. C. Moon, "Diurnal characteristics of volatile organic compounds in the Seoul atmosphere," Atmospheric Environment, vol. 37, no. 6, pp. 733-742, 2003.

[8] C. Chang, U. Sree, Y. Lin, and J. Lo, "An examination of 7:009:00 PM ambient air volatile organics in different seasons of Kaohsiung city, southern Taiwan," Atmospheric Environment, vol. 39, no. 5, pp. 867-884, 2005.

[9] H. Cheng, H. Guo, X. Wang et al., "On the relationship between ozone and its precursors in the Pearl River Delta: application of an observation-based model (OBM)," Environmental Science and Pollution Research, vol. 17, no. 3, pp. 547-560, 2010.

[10] S. Saito, I. Nagao, and H. Kanzawa, "Characteristics of ambient $\mathrm{C}_{2}-\mathrm{C}_{11}$ non-methane hydrocarbons in metropolitan Nagoya, Japan," Atmospheric Environment, vol. 43, no. 29, pp. 4384-4395, 2009.

[11] R. Atkinson, Kinetics and Mechanisms of the Gasphase Reactions of the Hydroxyl Radical with Organic Compounds, American Institute of Physics, New York, NY, USA, 1989.

[12] W. P. L. Carter, "Development of ozone reactivity scales for volatile organic compounds," Journal of the Air and Waste Management Association, vol. 44, no. 7, pp. 881-899, 1994.

[13] D. R. Blake, D. F. Hurst, J. T. W. Smith et al., "Summertime measurements of selected nonmethane hydrocarbons in the Arctic and Subarctic during the 1988 Arctic Boundary Layer Expedition (ABLE 3A)," Journal of Geophysical Research: Atmospheres, vol. 97, no. 15, pp. 16559-16588, 1992.

[14] Y. H. Zhang, H. Su, L. J. Zhong et al., "Regional ozone pollution and observation-based approach for analyzing ozoneprecursor relationship during the PRIDE-PRD2004 campaign," Atmospheric Environment, vol. 42, no. 25, pp. 6203-6218, 2008.

[15] M. Wang, H. Cheng, G. Ding et al., "Study on the composition of NMHCs and the variation of concentration at Linan and Shangdianzi atmospheric background station," Acta Meteorologica Sinica, vol. 64, pp. 658-665, 2006.
[16] M. Wang, H. Cheng, G. Ding et al., "The primary study of measured result of ambient VOCs in Beijing areas," Journal of Applied Meteorological Science, vol. 16, no. 5, pp. 600-607, 2005.

[17] J. H. Tang, L. Y. Chan, C. Y. Chan et al., "Characteristics and diurnal variations of NMHCs at urban, suburban, and rural sites in the Pearl River Delta and a remote site in South China," Atmospheric Environment, vol. 41, no. 38, pp. 8620-8632, 2007.

[18] M. Shao, Y. Zhang, L. Zeng et al., "Ground-level ozone in the Pearl River Delta and the roles of VOC and $\mathrm{NO}_{x}$ in its production," Journal of Environmental Management, vol. 90, no. 1, pp. 512-518, 2009.

[19] E. G. Olumayede and J. M. Okuo, "Ambient air pollution and assessment of ozone creation potential for reactive Volatile Organic Compounds in atmosphere of Southwestern, Nigeria," Nigeria African Journal of Environmental Science and Technology, vol. 7, no. 8, pp. 815-823, 2013.

[20] E. G. Olumayede and J. M. Okuo, "Variation characteristics of volatile organic compounds in an urban atmosphere in Nigeria," Polish Journal of Environmental Studies, vol. 21, no. 1, pp. 177186, 2012.

[21] E. G. Olumayede and J. M. Okuo, "Baseline levels of volatile organic compounds in atmosphere of two Urban Centres of Southwestern, Nigeria Intern," Journal of Chemical Science, vol. 4, no. 1, pp. 42-55, 2011.

[22] J. M. Okuo, C. C. Ojiodu, and E. G. Olumayede, "Ambient air pollution by Volatile Organic Compounds (VOCs) in Ikeja industrial areas of Lagos State, Southwestern Nigeria," Nigerian Journal of Applied Science, vol. 30, pp. 138-149, 2012.

[23] NMA, "Nigerian Meteorological Agency," Weather Report Bulletin, 2009.

[24] ASTM, "Method D3686-84: standard practice for sampling atmospheres to collect organic compound vapours," in Annual Book of ASTM Standards, vol. 11, 03, pp. 234-240, 1988.

[25] "National Population Commission (NPC) Nigeria 2006 census Final Results," Official Gazette, Federal Republic of Nigeria, vol. 96, no. 2, 2009.

[26] P. A. O. Odjugo, "Regional evidence of climate change in Nigeria," Journal of Geography and Regional Planning, vol. 3, no. 6, pp. 142-150, 2010.

[27] W. L. Chameides, F. Fehsenfeld, M. O. Rodgers et al., "Ozone precursor relationships in the ambient atmosphere," Journal of Geophysical Research, vol. 97, no. 5, pp. 6037-6055, 1992.

[28] E. A. Woolforenden, "Use of diffusive sampler with thermal desorption- capillary GC analysis for monitoring volatile organic compounds in ambient air. Summary of reported data and practices," Technical Support Document, Mark International, Bradford, UK.

[29] H. U. Pferffer, L. Brever, and K. Ellermann, "Validation of hydrocarbon diffusive tubes for ambient air monitoring," LUA Report 46, 1998.

[30] W. P. L. Carter and R. Atkinson, "Computer modeling study of incremental hydrocarbon reactivity," Environmental Science \& Technology, vol. 23, no. 7, pp. 864-880, 1989.

[31] E. E. Ukpebor, J. E. Ukpebor, F. Eromomene, J. I. Odiase, and D. Okoro, "Spatial and diurnal variations of Carbon monoxide (CO) pollution from motor vehicles in an Urban centre," Polish Journal of Environmental Studies, vol. 19, no. 4, pp. 817-823, 2010.

[32] J. H. Seinfeld and S. N. Pandis, Atmospheric Chemistry and Physics: From Air Pollution to Climate Change, Wiley, New York, NY, USA, 1998. 
[33] J. H. Tan, S. J. Guo, Y. L. Ma et al., "Non-methane hydrocarbons and their Ozone formation potentials in Foshan," Aerosol and Air Quality Research, vol. 12, pp. 387-398, 2012.

[34] H. Guo, K. L. So, I. J. Simpson, B. Barletta, S. Meinardi, and D. R. Blake, " $\mathrm{C}_{1}-\mathrm{C}_{8}$ volatile organic compounds in the atmosphere of Hong Kong: overview of atmospheric processing and source apportionment," Atmospheric Environment, vol. 41, no. 7, pp. 1456-1472, 2007.

[35] H. Singh and P. B. BZimmermon, Wiley Services on Advance in Environment Science and Technology, vol. 24, 1992, edited by O. Nriagu. 

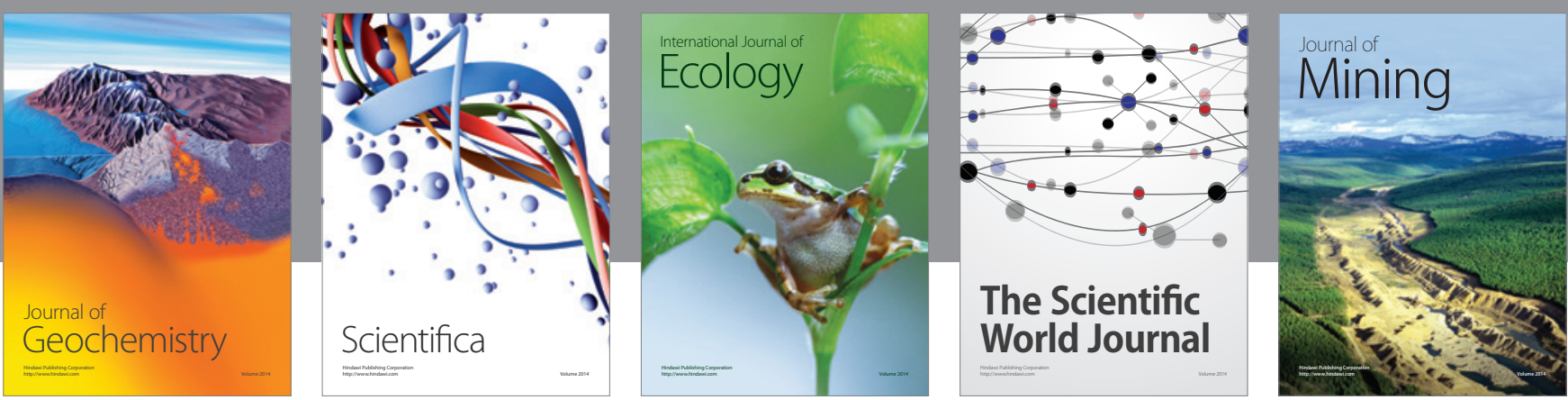

The Scientific World Journal
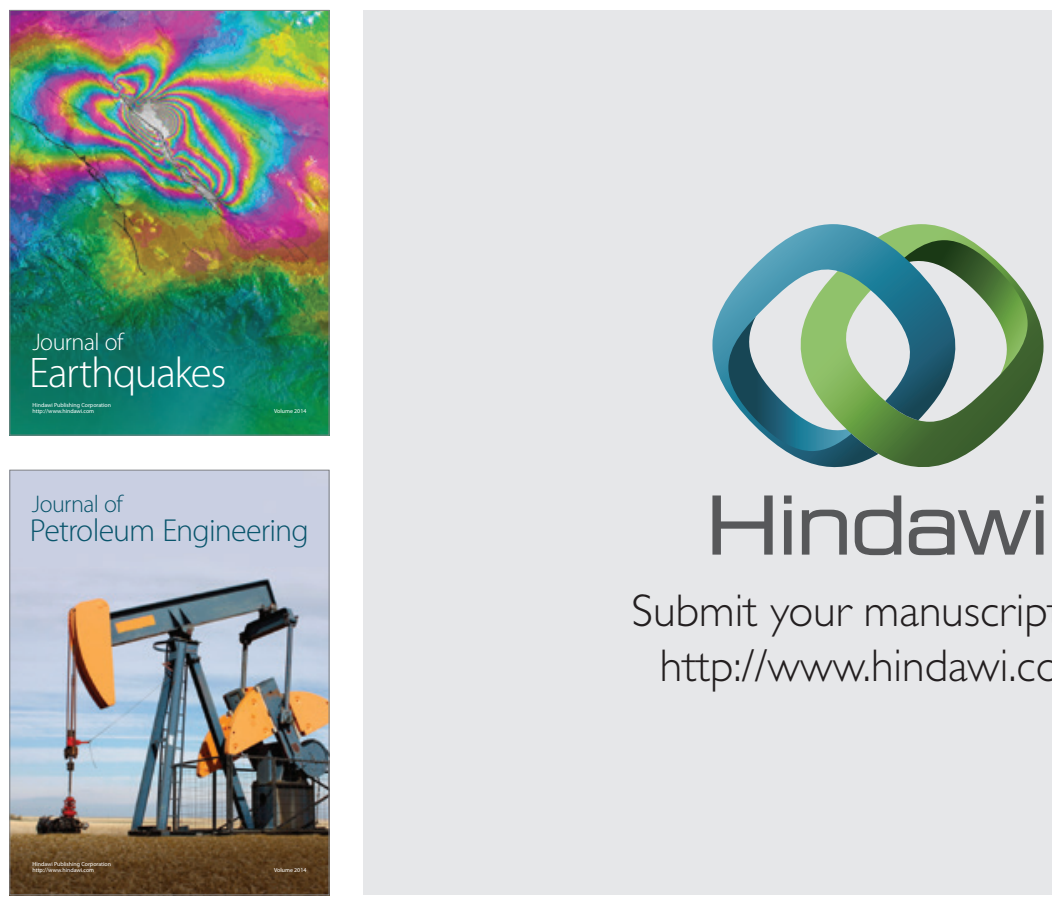

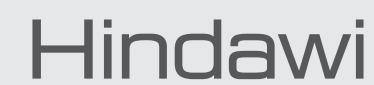

Submit your manuscripts at

http://www.hindawi.com
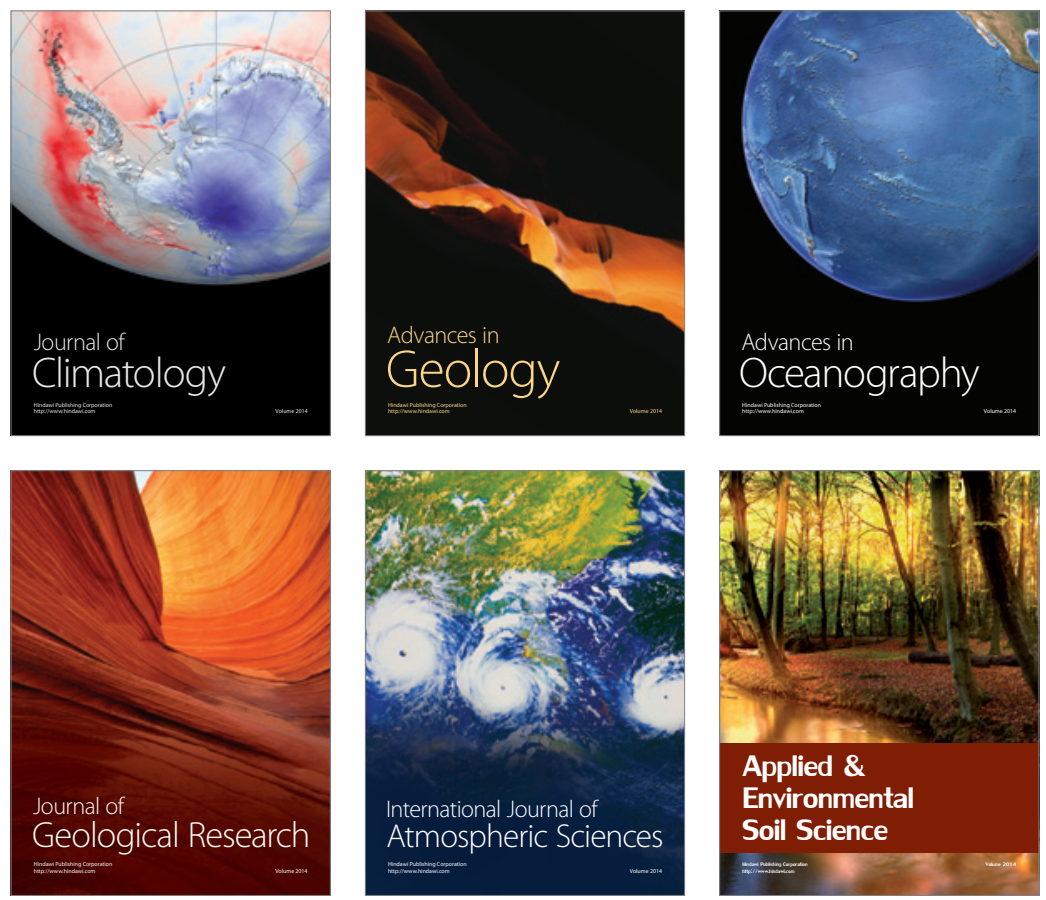
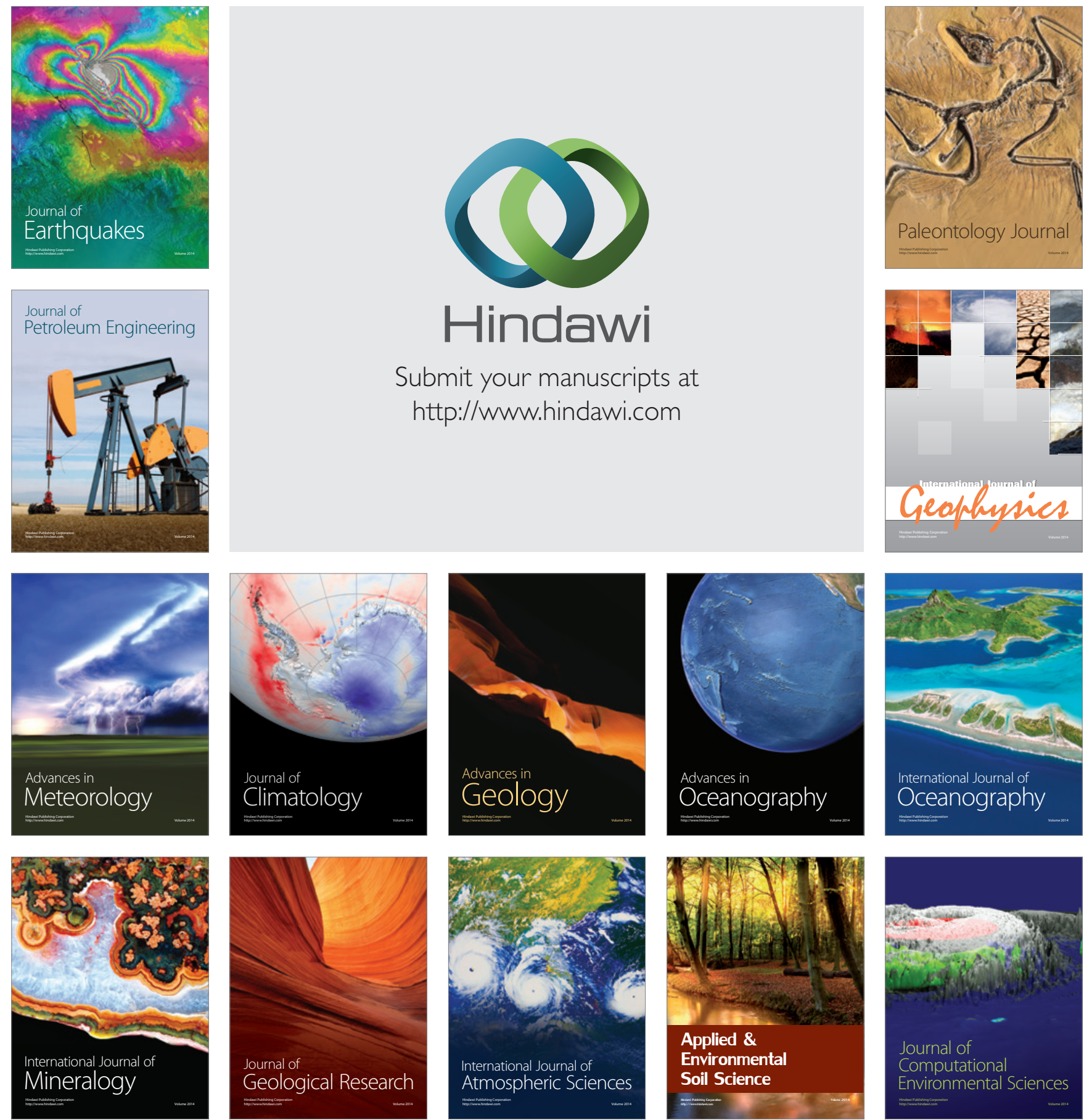